\title{
ANALISIS VARIANS BELANJA LANGSUNG: PADA PEMERINTAH DAERAH
}

\author{
Mirna Amirya \\ Kristin Rosalina \\ Fakultas Ekonomi dan Bisnis Universitas Brawijaya \\ Jl. Mayjen Haryono No. 165 Malang \\ Email: mirna.amiryasecret@gmail.com
}

Abstract

This research is a descriptive study based on the case study method which aims to analyze the direct expenditure variances that occur in Local Government " $X$ ". The data are used as materials analysis in this research are primary and secondary data obtained by interviewing directly to the related officials and also documentation of APBD realization report of Local Government " $X$ " in 2011 and 2012. The Results showed there was a direct expenditure variance of Local Government " $X$ " in 2011 and 2012 in which the budget is greater than the realization. The most significant variances exist in the capital expenditure component. Whereas the unit that has the highest direct expenditure variance is SKPD Department of Education. From this research also detected that one of the causes of variances is the budgeting system still refers to the incremental budgeting system, has not been implementing comprehensive and substantial performance-based budgeting system.

Keywords: direct expenditure, the incremental budgeting system

Abstrak:

Penelitian ini adalah kajian deskriptif yang berdasarkan metode studi kasus yang menganalisis varians belanja langsung yang terjadi di Pemerintahan X. Data yang digunakan sebagai analisis material dalam penelitian yaitu data utama dan pendukung. Data tersebut didapatkan dengan melakukan wawancara langsung terhadap para pegawai terkait dan paparan dari dokumen laporan realisasi APBD 
pemerintah daerah X di tahun 2011 dan 2012. Hasilnya menunjukkan adanya varians belanja secara langsung pemerintah daerah X di tahun 2011 dan 2012 dalam belanja yang lebih besar dari kenyataannya. Keberadaan varians yang paling signifikan dalam komponen belanja modal. Sementara bagian yang memiliki varians belanja langsung paling tinggi adalah SKPD bagian pendidikan. Dari penelitian ini juga ditemukan satu dari beberapa kasus varians yang sistem pembelanjaannya masih mengarah kepada sistem belanja kenaikan gaji yang tidak terimplementasikan secara komprehensif dan sistem belanja yang berbasis kinerja substansial.

Kata kunci: belanja langsung, sistem belanja incremental

\section{PENDAHULUAN}

Salah satu hasil temuan dari evaluasi belanja modal daerah yang dilakukan oleh Direktorat Jenderal Perimbangan Keuangan (DJPK) Kementerian Keuangan Republik Indonesia (2013) menjelaskan bahwa realisasi belanja modal di daerah pada akhir tahun anggaran seringkali masih di bawah target atau lebih rendah dibandingkan dengan anggarannya. Sebelumnya di tahun 2010, Pemerintah Daerah Provinsi Jawa Barat juga mengalami selisih lebih anggaran belanja dibandingkan dengan realisasinya hingga mencapai kisaran 50 miliar rupiah $^{1}$. Kasus serupa juga dialami oleh Pemerintah Daerah Khusus Ibukota Jakarta di tahun 2013 yang tingkat penyerapan anggaran belanjanya hingga akhir Oktober masih sangat rendah, yakni baru sebesar 42,42 persen dari total keseluruhan Anggaran Pendapatan dan Belanja Daerah (APBD) DKI 2013².

Adanya varians lebih anggaran belanja pemerintah daerah atas realisasinya seperti yang dicontohkan oleh beberapa kasus di atas salah satunya diduga karena kurang baiknya fungsi perencanaan dan pelaksanaan kegiatan di daerah (DJPK, 2013). Selanjutnya, faktor yang juga disinyalir turut menjadi sebab terjadinya selisih lebih anggaran belanja pemerintah daerah adalah kondisi-kondisi yang bersifat eksogen seperti perubahan kondisi ekonomi, politik, dan kebijakan pemerintah pusat (Kuncoro, 2008).

Argumentasi lain terkait dengan kecenderungan adanya varians anggaran belanja pada institusi sektor publik dinyatakan oleh Raghunandan dkk. (2012) yang menganggap bahwa proses penyusunan anggaran tidak akan bisa lepas dari aspek

\footnotetext{
${ }^{1}$ Dikutip dari http://www.neraca.co.id/article/3293/PEMPROV-JABAR-DAN-PEMKOTBANDUNG-SELISIH-PAHAM-Pembangunan-SUS-Gedebage-Dirundung-Masalah-Dana dengan judul Pemprov Jabar Dan Pemkot Bandung Selisih Paham Pembangunan SUS Gedebage Dirundung Masalah Dana (Diakses tanggal 13 Juni 2013)

${ }^{2}$ Dikutip dari http://www.bppk.depkeu.go.id/bdk/yogyakarta/index.php?option=com_ content \& view $=$ article $\& \mathrm{id}=445$ : akhir-tahun-anggaran-optimalisasi-vs-pemborosan \&catid=3:berita $\&$ Itemid= 11 dengan judul Akhir Tahun Anggaran, Optimalisasi vs Pemborosan (Diakses tanggal 13 Juni 2014).
} 
perilaku penyusun anggaran, kebijakan-kebijakan politik, sindrom "spend it or lose it”, serta tidak diukur berdasarkan target kinerja yang hendak dicapai. Berbagai orientasi tersebut kemudian membuat anggaran cenderung menjadi bias. Apa yang dinyatakan oleh Raghunandan dkk. (2012) nampaknya sejalan dengan pendapat Anthony (1985) yang menjabarkan adanya semacam keumuman terkait penyelarasan antara realisasi dengan anggaran pendapatan dan belanja sehingga tidak berdampak pada pemotongan anggaran periode berikutnya.

Adapun hasil kajian empiris terkait dengan Proses Penyusunan Anggaran Daerah di Indonesia sebelumnya dilakukan oleh Rahayu dkk. (2007). Dari penelitian tersebut ditemukan bahwa dalam menyusun anggarannya, pemerintah daerah dihadapkan oleh beberapa masalah seperti singkatnya waktu yang dialokasikan, rendahnya tingkat keterwakilan Satuan Kerja (Satker) yang menjadi undangan dalam musrenbang, serta masih digunakannya pendekatan incremental budgeting dalam penentuan plafon anggaran (menaikan dari plafon anggaran tahun sebelumnya dengan tingkat persentase tertentu).

Berbagai kajian terkait dengan proses penyusunan anggaran serta bukti empiris dari hasil penelitian yang telah dijabarkan sebelumnya tentunya bertentangan dengan konsep performance-based budgeting yang menganggap bahwa setiap anggaran harus disusun dengan berorientasi pada output organisasi serta berkaitan erat dengan visi, misi, sasaran kerja, dan rencana strategis organisasi (Bastian, 2006; Mardiasmo, 2009). Proses penyusunan anggaran dengan tidak mendasarkan kepada konsep performance-based budgeting inilah yang kemudian disinyalir menjadi salah satu penyebab utama terjadinya selisih antara apa yang dianggarkan dengan apa yang direalisasikan (Rahayu dkk, 2007).

Berlandaskan pada fenomena-fenomena di atas, selanjutnya penelitian ini dilakukan dengan tujuan untuk menganalisis kinerja belanja langsung, yang diukur dari varians antara anggaran dengan realisasinya, serta penyebab dari adanya varians tersebut di salah satu pemerintah kabupaten di Indonesia. Selanjutnya pemerintah kabupaten dimaksud dalam penelitian ini disebut dengan pemda "X". Adapun penggunaan belanja langsung sebagai obyek analisis dalam penelitian ini karena jenis belanja ini memiliki keterkaitan secara langsung dengan program dan kegiatan dari pemda (Halim, 2007).

\section{TINJAUAN TEORI ATAS ANALISIS BELANJA LANGSUNG}

\section{Institutional Theory}

Dalam kajiannya Scott (2004) menjelaskan bahwa institutional theory menjadi aspek yang penting dalam menjelaskan sebuah struktur sosial, yaitu suatu proses tentang struktur, termasuk di dalamnya adalah skema, aturan, norma, serta rutinitas, yang keseluruhannya itu kemudian menjadi landasan bagi perilaku sosial. Teori ini menyelidiki tentang bagaimana sebuah elemen diciptakan, disebarkan, diadaptasi, 
dan dipertahankan. Adapun yang dimaksud elemen dalam hal ini menurut Scott (2004) terdiri dari elemen budaya-kognitif, elemen normatif, dan elemen regulatif.

Lebih jauh, masih terkait dengan teori institusionalisasi, Meyer dan Rowan (1977:47) menyatakan bahwa organisasi dibentuk oleh berbagai fenomena yang terjadi dalam lingkungannya dan cenderung menjadi mirip (isomorphic) dengan lingkungan tersebut. Dihubungkan dengan konteks penelitian ini, keseluruhan organisasi sektor publik, yang mana pemerintah daerah salah satunya, harus mengimplementasikan sistem anggaran berbasis kinerja sebagai mandat dari undang-undang yang ada. Adapun implementasi sistem anggaran berbasis kinerja di organisasi sektor publik di Indonesia salah satunya didasarkan pada keberhasilan pengimplementasiannya di negara-negara lain seperti contohnya New Zealand dan Australia.

Lebih lanjut, terkait dengan proses institusionalisasi itu sendiri, Di Maggio dan Powell (1983:67); Carruthers (1995); Lippi (2000); dan Sewing (2010:123) menyatakan tiga jenis faktor atau kondisi eksogen yang menyebabkan terjadinya institutional isomorphism, yakni (1) coercive isomorphism, (2) mimetic isomorphism, dan (3) normative isomorphism. Faktor pendorong yang pertama bersifat coercive (paksaan), yakni isomorphism yang muncul karena desakan formal maupun informal pada suatu organisasi, baik berasal dari organisasi lainnya kondisi budaya di masyarakat sekitar, maupun regulasi yang ada dan diimplementasikan. Di lain pihak, kondisi yang ada di sekitar organisasi kadang kala juga bisa menjadi tekanan yang kuat untuk melakukan perubahan organisasi dengan cara mereplikasi (mimetic) organisasi lain untuk aspek-aspek tertentu yang berkarakteristik sejenis. Sedangkan normative adalah bentuk isomorphic yang dilandasi dengan penekanan pada profesionalisme dan substansi keperluan. Larson (1977) dan Collins (1979) menyatakan bahwa yang dimaksud dengan profesionalisme dan substansi keperluan adalah adanya berbagai daya upaya dari komponen organisasi untuk membentuk kondisi dan metode kerja mereka dan untuk menetapkan dasar kognitif serta perolehan legitimasi.

Pada akhirnya, yang patut diperhatikan terkait dengan proses institusionalisasi adalah munculnya dampak decoupling (Meyer dan Rowan, 1977:57). Arti dari decoupling adalah internalisasi elemen-elemen asing oleh sebuah organisasi, di mana internalisasi tersebut sudah tidak sama dengan arti atau peran sesungguhnya namun sudah memiliki nilai yang lain (baru) sehingga apa yang diinternalisasikan oleh organisasi tersebut telah decoupled dari konteks aslinya. Decoupling juga terjadi karena besarnya peran dan pengaruh faktor endogen, yang oleh Meyer (1996:241-252) disebut "others" yang mampu menengahi dan meneruskan elemen baru pada sebuah organisasi. 


\section{Anggaran Sektor Publik dan Anggaran Berbasis Kinerja (Performance- based Budgeting)}

Menurut Mardiasmo (2009:62), anggaran publik berisi rencana kegiatan yang direpresentasikan dalam bentuk rencana perolehan pendapatan dan belanja dalam satuan moneter. Dalam bentuk yang paling sederhana, anggaran publik merupakan suatu dokumen yang menggambarkan kondisi keuangan dari suatu organisasi yang meliputi informasi mengenai pendapatan, belanja, dan aktivitas. Anggaran berisi estimasi mengenai apa yang akan dilakukan organisasi di masa yang akan datang. Setiap anggaran memberikan informasi mengenai apa yang hendak dilakukan dalam beberapa periode yang akan datang. Interpretasi anggaran secara ringkaspun juga dinyatakan oleh Bastian (2006:163), yakni "sebagai paket pernyataan perkiraan penerimaan dan pengeluaran yang diharapkan akan terjadi dalam satu atau beberapa periode mendatang".

Adapun anggaran berbasis kinerja (performance-based budgeting) merupakan alat manajerial untuk mengalokasikan anggaran dana berdasarkan program yang direncanakan dalam rangka mencapai outcomes yang diinginkan (Gilmour dan Lewis, 2005; Hou dkk. 2011). Dengan pengimplementasian anggaran berbasis kinerja, maka setiap dana yang dikeluarkan dapat diukur kebermanfaatannya, kegiatan yang dijalankan menggunakan dana tersebut dapat diukur kinerjanya, hingga pada akhirnya terjadi efisiensi dan efektifitas dalam pencapaian tujuan dari organisasi.

Dalam perspektif organisasi sektor publik, penerapan performance-based budgeting sebagai alat penganggaran disinyalir mampu memicu perbaikan mutu pelayanan publik dan peningkatan atas outcomes pelayanan yang diberikan. Hal tersebut dicapai melalui pendesentralisasian wewenang yang lebih besar kepada penyelenggara kegiatan pelayanan publik yang berada di level bawah (let's the manager manage) untuk mengelola program dan kegiatan. Pendesentralisasian wewenang tentunya didukung dengan adanya tingkat kepastian yang lebih tinggi atas pembiayaan untuk program dan kegiatan yang akan diselenggarakan, karena pada dasarnya titik tekan sistem performance-based budgeting adalah setiap penggunaan dana yang dianggarkan harus ditujukan untuk merealisasikan sasaran atas program yang terangkum dalam rencana strategik organisasi (Sancoko dkk, 2008; Andriani dan Hatta, 2012).

Glaser (2007) dalam Shah (2007) menjelaskan bahwa pengimplementasian performance based budgeting mengarahkan pada pembentukan pemerintahan yang akuntabel. Hal tersebut dikarenakan pengukuran kinerja dalam organisasi selalu dilandaskan pada tujuan yang telah tercapai atas kegiatan-kegiatan yang sebelumnya diprogramkan dengan dana yang telah dianggarkan atasnya. Adapun Schick (1996) dalam kajiannya menjelaskan bahwa kunci pokok untuk memahami performance-based budgeting adalah pada kata "performance". Kinerja dalam hal ini dijadikan sebagai tujuan utama atas setiap penganggaran dan pengalokasian 
dana yang dilakukan. Oleh karenanya, pengimplementasian performance-based budgeting juga memerlukan alat ukur kinerja yang jelas dan transparan berupa indikator kinerja (performance indicator), adanya sasaran (targets) yang jelas, juga rencana strategis yang matang (Hou dkk. 2011). Kondisi demikian ditujukan agar kinerja dapat diukur dan diperbandingkan sehingga selanjutnya dapat dinilai efisiensi dan efektivitas dari aktivitas yang dilaksanakan juga atas setiap uang yang telah diserap.

Di Indonesia sendiri, keberadaan Undang-Undang No. 17 Tahun 2003 tentang Keuangan Negara menjadi landasan pengimplementasian konsep anggaran berbasis kinerja dan menggantikan sistem anggaran tradisional (traditional budgeting) yang sebelumnya diimplementasikan di organisasi sektor publik (Andriani dan Hatta, 2012). Sebagai tindak lanjut atas UU No. 17 Tahun 2003, Pemerintah pun telah mengeluarkan PP No 20 tahun 2004 tentang Rencana Kerja Pemerintah (RKP) dan PP No 21 tahun 2004 tentang Penyusunan Rencana Kerja dan Anggaran Kementerian/Lembaga (RKA-KL) sebagai operasionalisasi kebijakan sistem penganggaran berbasis kinerja (Wahyuni, 2007).

\section{Belanja Langsung}

Menurut Peraturan Menteri Dalam Negeri No. 13 Tahun 2006 Pasal 36 tentang Pedoman Pengelolaan Keuangan Daerah, belanja langsung merupakan belanja yang dianggarkan terkait secara langsung dengan pelaksanaan program dan kegiatan. Belanja langsung terdiri dari belanja pegawai, belanja barang dan jasa, serta belanja modal.

Belanja pegawai adalah belanja kompensasi, baik dalam bentuk uang maupun barang yang ditetapkan berdasarkan peraturan perundang-undangan yang diberikan kepada pejabat negara, Pegawai Negeri Sipil (PNS), dan pegawai yang dipekerjakan oleh pemerintah yang belum berstatus PNS sebagai imbalan atas pekerjaan yang telah dilaksanakan di mana pekerjaan tersebut yang berkaitan dengan pembentukan modal. Sedangkan belanja barang dan jasa adalah pengeluaran untuk menampung pembelian barang dan jasa yang habis pakai untuk memproduksi barang dan jasa yang dipasarkan maupun tidak dipasarkan, dan pengadaan barang yang dimaksudkan untuk diserahkan atau dijual kepada masyarakat dan belanja perjalanan. Adapun yang dimaksud dengan belanja modal adalah pengeluaran anggaran untuk perolehan aktiva tetap dan aset lainnya yang memberi manfaat lebih dari satu periode akuntansi. Untuk mengetahui apakah suatu belanja dapat dimasukkan sebagai belanja modal atau tidak, maka perlu diketahui definisi aset tetap atau aset lainnya dan kriteria kapitalisasi aset tetap. 


\section{METODE PENELITIAN}

Jenis penelitian ini merupakan penelitian kualitatif dengan metode studi kasus tunggal dengan multi sumber bukti yang bersifat eksploratoris. Yin (2004:18) menjelaskan bahwa studi kasus merupakan suatu penelitian empirik yang menyelidiki keadaan yang terjadi pada masa sekarang dalam realita kehidupan yang bersifat nyata, ketika batas antara gejala dengan latar tidak secara jelas terbukti, dan bilamana berbagai sumber bukti digunakan. Adapun studi kasus menurut Ball (2004:92) merupakan analisis terhadap single unit secara mendalam yang holictic dan exhaustive yang bersandar pada karakteristik yang penuh arti dari kejadian nyata.

Dalam penelitian kualitatif, peneliti sebagai human instrument berfungsi menetapkan fokus penelitian, memilih informan sebagai sumber data, melakukan pengumpulan data, menilai kualitas data, analisis data, menafsirkan data, dan membuat kesimpulan atas temuannya (Sugiyono, 2005:60). Data yang digunakan dalam penelitian ini adalah data primer dan data sekunder. Data primer adalah data yang diperoleh melalui proses pemberian langsung data kepada pengumpul data (Sugiyono, 2005:62). Data primer didapatkan oleh peneliti melalui serangkaian proses dokumentasi dan wawancara dengan obyek penelitian, dalam hal ini adalah pemangku jabatan di beberapa unit kerja dalam satu satuan kerja organisasi sektor publik yang berurusan dengan proses penyusunan anggaran. Selanjutnya, data sekunder yang tidak langsung memberikan data kepada pengumpul data dalam penelitian ini adalah Laporan Realisasi Anggaran Pendapatan Dan Belanja Daerah Pemda X untuk tahun anggaran 2011 dan 2012.

Teknis analisis data dalam penelitian ini dilakukan melalui proses mencari dan menyusun secara sistematis data yang diperoleh dari hasil wawancara, catatan lapangan, dan bahan-bahan lain, sehingga dapat mudah dipahami, dan temuannya dapat diinformasikan kepada orang lain (Sugiyono, 2005:88). Adapun secara sistematis, tahapan teknik analisis data dalam penelitian ini mengacu pada Miles dan Huberman (1992:20) yang membagi menjadi tiga tahapan, yaitu reduksi data (data reduction), penyajian data (data display), penarikan kesimpulan/verifikasi.

\section{HASIL DAN ANALISIS}

\section{Analisis Varians Belanja Langsung}

Analisis varians adalah suatu proses sistematis untuk mengidentifikasi, melaporkan dan menjelaskan varians atau penyimpangan hasil yang sesungguhnya dari hasil yang diharapkan atau dianggarkan (Carter dan Usry, 2004). Dalam kaitannya dengan pembahasan belanja langsung Pemda $X$ sebagai obyek dalam penelitian ini dan dihubungkan dengan pengertian tersebut di atas, kemudian dapat ditarik kesimpulan bahwa analisis varians belanja langsung pemerintah daerah adalah proses sistematis untuk mengidentifikasi, melapor dan menjelaskan 
penyimpangan realisasi belanja langsung dari anggaran belanja langsung yang telah ditetapkan sebelumnya oleh Pemda $\mathrm{X}$, menentukan penyebab terjadinya varians belanja langsung dan menganalisis beberapa kemungkinan dampak serta alternatif solusi atas terjadinya varians tersebut.

Analisis varians dalam penelitian ini dilakukan untuk setiap komponen belanja langsung yaitu belanja pegawai, barang dan jasa, dan modal. Selain itu, analisis varians belanja langsung juga dapat dilakukan untuk setiap Satuan Kerja Perangkat Daerah (SKPD) yang menjadi subjek belanja di Pemda X dalam rangka mengetahui tingkat penyerapan anggaran serta peyimpangan realisasi belanja dengan anggaran atas masing-masing urusan yang dijalankan.

\section{a. Analisis Varians Total Belanja Langsung}

Analisis varians belanja langsung Pemda X tahun 2011-2012 dilakukan dengan mendasarkan informasi yang ada dalam Anggaran Pendapatan dan Belanja Daerah (APBD) dengan Laporan Realisasi Anggaran (LRA) Pemda X tahun 2011-2012. Analisis varians belanja sendiri dilakukan dengan jalan mencari selisih antara realisasi belanja yang ada di LRA dengan jumlah anggaran belanja yang diinformasikan dalam APBD.

Dengan membandingkan data dari kedua sumber tersebut, kemudian secara garis besar, gambaran dari analisis varians belanja langsung Pemda X tahun 20112012 .

Tabel 1. Varians Belanja Langsung

\begin{tabular}{ccccc}
\hline TAHUN & $\begin{array}{c}\text { Anggaran setelah } \\
\text { perubahan }\end{array}$ & Realisasi & $\%$ & Sisa Lebih Anggaran \\
\hline 2011 & $707,131,404,011$ & $520,509,334,677$ & $74 \%$ & $186,622,069,334$ \\
2012 & $919,710,037,950$ & $725,034,197,541$ & $79 \%$ & $194,675,840,409$ \\
\hline
\end{tabular}

Sumber: Data sekunder diolah, 2014.

Dari tabel tersebut dapat diketahui bahwa terjadi varians lebih anggaran total belanja langsung Pemda X baik di tahun anggaran 2011 maupun di tahun anggaran 2012 jika dibandingkan dengan realisasinya. Untuk tahun 2011 realisasi belanja langsung hanya mencapai $74 \%$ dari anggaran dengan selisih lebih anggaran sebesar Rp186,622,069,334, sedangkan realisasi di tahun 2012 hanya mencapai 79\% dari anggaran dengan selisih lebih anggaran adalah sebesar Rp194,675,840,409.

Terdapat suatu acuan bahwa anggaran belanja merupakan batas maksimum dari dana yang dikeluarkan oleh pemerintah daerah. Kinerja pemerintah akan dinilai baik ketika jumlah belanja yang direalisasikan tidak melebihi jumlah yang telah dianggarkan sebelumnya (Kainde, 2013). Hal ini senada dengan apa yang dikemukakan oleh Vinnari dan N'Asi (2008) yang menyatakan bahwa pada dasarnya pengukuran derajat kewajaran aktivitas ekonomi ataupun keuangan di suatu 
organisasi sektor publik akan sangat ditentukan oleh tingkat kesesuaian antara anggaran dengan realisasinya, yang salah satunya adalah pada area belanja pemerintah.

Selanjutnya, dalam konteks analisis varians belanja langsung Pemda $\mathrm{X}$ tahun anggaran 2011 dan 2012, kondisi varians belanja langsung yang terjadi di Pemda X untuk tahun anggaran 2011 dan 2012 ini, di satu sisi secara sederhana dapat dinyatakan bahwa terjadi efisiensi penggunaan anggaran dan baiknya kinerja pemerintah karena pada dasarnya kondisi kinerja dari pemerintah dinyatakan buruk ketika terjadi varians belanja yang tidak menguntungkan di mana posisi realisasi belanja lebih besar jika dibandingkan dengan anggarannya (unfavourable variance). Namun yang perlu dicermati dan menjadi perhatian penting selanjutnya adalah ketika varians menguntungkan atau selisih lebih anggaran yang terjadi terlalu besar, maka sesungguhnya akan berakibat buruk juga bagi pemerintah yang bersangkutan di mana akan memberikan dampak pemotongan distribusi anggaran pada periode berikutnya (Anthony, 1985).

Hal ini selaras dengan apa yang pernah disampaikan oleh Bapak $\mathrm{Bei}^{3}$ sebagai salah satu pejabat yang bertanggung jawab atas pembuatan anggaran Pemda X. Beliau menjelaskan bahwa Pemda-nya ingin menerapkan prinsip efisiensi dan efektivitas layaknya tujuan ideal atas implementasi anggaran berbasis kinerja, namun di lain pihak, anggaran juga harus didasarkan pada kebutuhan yang sebenarnya. Berikut penjelasannya:

"Sebenarnya kami ingin menerapkan prinsip efisiensi dan efektivitas, juga inginnya ndak menargetkan SILPA yang terlalu besar di akhir tahun. Kami lebih menginginkan agar anggaran tersebut mendekati kebutuhan riil dan tentunya masih kelihatan wajar dibandingkan anggaran tahun-tahun sebelumnya".

Selisih lebih anggaran belanja langsung yang cukup signifikan seperti apa yang dialami oleh Pemda X dapat dijadikan sebagai indikasi adanya kelemahan dan kekurangtepatan aktivitas proyeksi anggaran belanja langsung yang dilakukan oleh masing-masing Satuan Kerja Perangkat Daerah (SKPD). Sedangkan indikasi lainnya yang juga bisa dideteksi untuk kemudian mencari akar masalah dan pemecahan dari masalah yang terjadi adalah tidak terealisasi dan tercapainya secara $100 \%$ program kerja yang telah dicanangkan.

Terjadinya selisih lebih anggaran belanja langsung yang cukup signifikan pada Pemda X bisa jadi dipicu oleh sistem perumusan dan penyusunan anggaran yang masih sebagian besar mengacu pada anggaran dan realisasi tahun lalu saja (sistem incremental budgeting), tidak berdasarkan pada analisis kebutuhan atas kinerja

\footnotetext{
${ }^{3}$ Bapak Bei adalah nama samaran.
} 
dan program-program yang hendak dicapai dalam rencana strategis (prinsip dari sistem penganggaran berbasis kinerja). Seharusnya besar kecilnya anggaran akan selalu mengikuti setiap program dan capaian kinerja yang dicanangkan, adapun program yang dicanangkan haruslah diturunkan melalui visi, misi, dan rencana strategis dari pemerintah daerah yang bersangkutan. Dengan pola semacam itu, pastilah keterserapan belanja akan bisa optimal karena sesuai dengan program kerja yang dicita-citakan. Kondisi perumusan dan penentuan anggaran belanja, khususnya belanja langsung, di Pemda $\mathrm{X}$ yang hingga saat ini masih berlangsung adalah sesuai dengan apa yang diungkapkan oleh Bapak Bei sebagai berikut:

"Ya, sebenarnya kita ngerti kalau seharusnya anggaran itu harus mengacu pada prinsip anggaran berbasis kinerja. Kita juga sudah sering dapat sosialisasi tentang itu. Bahkan setiap kali ada pemeriksaan, kita selalu ditanya apakah anggaran sudah mengacu ke sana. Tapi kondisi di lapangan yang kelihatannya masih ndak mungkin. Biasanya sih masing-masingmasing SKPD menyusunnya dengan mengacu anggaran tahun lalu, dikirakira naik berapa persen. Mungkin juga karena waktu yang terbatas juga ya mbak, jadinya tetep seperti itu. Kondisi itu juga yang buat kita di sini pusing kalau harus diajak bicara tentang anggaran. Terus satu lagi mbak, setiap kita undang masing-masing perwakilan SKPD untuk kita ajak rapat tentang anggaran, kebanyakan antara satu rapat dengan rapat lainnya, yang datang dari masing SKPD itu orang yang berbeda-beda. Itu juga yang mungkin menyebabkan anggaran yang tersusun di masing-masing SKPD belum sesuai dengan harapan."

Pernyataan di atas nampakya senada dengan apa yang dinyatakan oleh Ibu $\mathrm{Putu}^{4}$, salah satu pejabat penyusun anggaran di salah satu satuan kerja di Pemda $\mathrm{X}$. Beliau menyampaikan bahwa beberapa anggaran kegiatan (belanja langsung) di SKPD-nya umumnya mengacu pada anggaran dan realisasi tahun-tahun sebelumnya. Berikut penuturannya:

"Biasanya, kalau kita buat anggaran, kita ngga bisa lepas dari anggaran dan realisasi tahun sebelumnya mbak. Bisa dibilang itu peta kita buat nyusun anggaran tahun berikutnya, mudah dan cepet mbak. Tapi yang jadi bikin bingung biasanya kalau kita mesti adep-adepan sama belanja yang belum diatur di Peraturan perundang-undangan. Biasanya kita masukin ke komponen kegiatan dan anggaran belanja langsung lain. Jadi, mungkin saja dalam anggaran yang kita susun, terutama belanja langsung

\footnotetext{
${ }^{4}$ Ibu Putu adalah nama samaran.
} 
ini, ada kegiatan yang telah kita anggarkan namun sebenarnya outputnya tidak sesuai dengan nama kegiatan yang dimaksud".

Selain Ibu Putu, Bapak Hendra ${ }^{5}$ selaku pimpinan di salah satu SKPD juga membenarkan hal tersebut:

"Beberapa SKPD diantaranya masih menganggarkan untuk anggaran tahun berikutnya melihat dari anggaran dan realisasi tahun-tahun sebelumnya. Kebanyakan belum paham sama apa itu sistem perencanaan dan penganggaran berbasis kinerja. Walaupun sebenarnya sudah bolak balik juga kita dapat sosialisasi tentang itu. Kalau saya ya lumayan paham prinsip anggaran berbasis kinerja, tapi ya gitu, mungkin susah juga kita maksa bagian penyusun anggaran buat mengimplementasikannya, waktunya juga mepet mbak."

Lebih lanjut, ketika ditanya tentang bagaimana mendefinisikan menyatakan target keluaran (output) atas anggaran (khususnya anggaran belanja langsung yang ditujukan untuk kegiatan dan program yang telah dicanangkan) ketika dalam menyusun anggaran hanya mendasarkan pada sistem incremental budgeting saja, Bapak Hendra menyatakan:

"Untuk target keluaran dari masing-masing jenis belanja saat kita membuat Dokumen Pelaksanaan Anggaran SKPD untuk masing-masing program, biar tidak menyulitkan kita tulis saja target outputnya $100 \%$. Itu kan sudah menandakan bahwa kita memang mentargetkan program yang kita canangkan itu bisa dilaksanakan seluruhnya."

Di lain pihak, terkait dengan pendefinisian target keluaran yang dicantumkan masing-masing SKPD dalam Dokumen Pelaksanaan Anggaran (DPA) untuk setiap program, Pak Bei menyatakan:

"Hingga saat ini, Pemda kita masih dihadapkan dengan masalah ketidakseragaman target keluaran yang dicanangkan oleh masing-masing SKPD atas program yang direncanakan. Sering kali, dalam DPA, meskipun jenis programnya sama, tapi kita menemukan target keluaran yang ndak sama antar satu SKPD dengan SKPD lainnya. Misalnya saja untuk program peningkatan kapasitas sumber daya aparatur dengan kegiatan pelatihan, SKPD A dalam DPA-nya menyatakan target keluarannya adalah $100 \%$, tapi SKPD B dengan program dan kegiatan yang sama di DPA-

\footnotetext{
${ }^{5}$ Bapak Hendra adalah nama samaran.
} 
nya malah mencantumkan target keluarannya adalah 1 tahun. Kayak gini ini kan jadi bingung, kita mau evaluasi juga akhirnya kesulitan. Sehingga wajar saja kalau akhirnya apa yang mereka anggarkan tidak bisa direalisasikan sepenuhnya."

Pernyataan tersebut menjelaskan bahwa salah satu faktor yang mempengaruhi ketidakoptimalan penyerapan belanja adalah karena pola pikir dan perilaku aparatur yang belum memahami sistem perencanaan dan penganggaran berbasis kinerja dan juga komitmen dari pimpinan yang masih lemah terhadap implementasi performance-based budgeting. Hal ini senada dengan pendapat Glaser (2007) dalam Shah (2007) bahwa keberhasilan implementasi anggaran berbasis kinerja dan perubahan organisasional yang positif menjadi beban berat yang ada di pundak pimpinan organisasi. Pendapat serupa juga dinyatakan oleh Hou dkk. (2011) bahwasannya keberhasilan penerapan anggaran berbasis kinerja bergantung mulai dari tahapan pelaksanaan perencanaan, penetapan tujuan, hingga pada penyusunan anggaran sendiri dengan didukung komitmen yang kuat dari seluruh perangkat organisasi, baik dari unsur legislatif maupun unsur eksekutifnya. Kondisi semacam itu dikarenakan pengaplikasian anggaran berbasis kinerja tidak akan bisa terlepas dari pengarus kebijakan-kebijakan politik yang diambil oleh pimpinan organisasi (Gilmour dan Lewis, 2005).

Dari pernyataan beberapa informan tersebut di atas, juga selanjutnya bisa disimpulkan beberapa poin yang menjadi penyebab varians lebih anggaran belanja langsung dibandingkan dengan realisasinya yang terjadi di Pemda $\mathrm{X}$ untuk tahun anggaran 2011 dan 2012. Beberapa poin dimaksud diantaranya adalah masih diterapkannya sistem incremental budgeting, adanya beberapa pengeluaran yang dilekatkan pada anggaran yang memiliki output yang berbeda dari output riil atas pengeluaran tersebut (saling silang penyusunan anggaran), hingga pada ketidakseragaman output yang dinyatakan oleh masing-masing SKPD untuk program dan kegiatan yang sama sehingga Pemda X sulit untuk menetapkan standar belanja atas masing-masing program serta melakukan evaluasi atas kinerja program yang telah direalisasikan. Pada akhirnya, kembali lagi, semua hal tersebut mengarah pada belum diinternalisasikannya secara menyeluruh sistem anggaran berbasis kinerja dalam penyusunan anggaran di Pemda X.

Terkait dengan masalah internalisasi sistem anggaran berbasis kinerja dalam Pemda X, nampaknya kenyataan ini sejalan dengan teori institusionalisasi yang menyatakan bahwa untuk melembagakan unsur-unsur tertentu (dalam hal ini adalah sistem anggaran berbasis kinerja), organisasi berupaya menjadi mirip (isomorphism) dengan lingkungan kelembagaan. Ada tiga cara yang bisa dilakukan. Tiga cara dimaksud adalah baik melalui coercive, mimetic, dan normative (Di Maggio dan Powell, 1983:67; Carruthers, 1995; Lippi, 2000; dan Sewing, 2010:123). Adapun apa yang dilakukan oleh Pemda X, nampaknya lebih mengarah ke coercive 
isomorphism yakni isomorphism yang terjadi karena dampak adanya tekanantekanan, baik itu yang sifatnya formal ataupun informal yang diterima oleh Pemda $\mathrm{X}$, tekanan tersebut berasal dari organisasi lainnya, budaya yang ada, hingga peraturan di masyarakat sekitar di mana organisasi tersebut berdiri.

Dalam hal ini, nampaknya penerapan sistem anggaran berbasis kinerja oleh Pemda $\mathrm{X}$ hanya sampai di permukaannya saja, belum diinternalisasikan secara menyeluruh ke semua perangkat yang ada di bawahnya. Penerapan secara coercive terlihat hanya sebatas dalam rangka memenuhi mandat undang-undang dan peraturan pemerintah saja, tanpa ingin melihat lebih jauh seberapa besar sebenarnya peran dan manfaat yang mungkin bisa diambil ketika Pemda X menerapkan sistem anggaran berbasis kinerja secara komprehensif.

Adapun dampak yang ditimbulkan sebagai akibat proses institusionalisasi yang tidak komprehensif atas sistem anggaran berbasis kinerja di Pemda X, maka selanjutnya terlihat adanya gejala decoupling yang mana pada akhirnya sistem anggaran berbasis kinerja tidak mampu berperan selayaknya peran idealnya. Salah satu dampak dari hal tersebut dapat dilihat dari adanya varians lebih anggaran belanja langsung yang signifikan atas realisasinya yang dialami oleh Pemda X di tahun 2011 dan 2012. Dikatakan sistem anggaran berbasis kinerja tidak mampu berperan selayaknya peran sesungguhnya yang bisa diberikan oleh sistem ini, karena seharusnya varians yang cukup signifikan tidak akan terjadi ketika anggaran benarbenar disusun dengan menerapkan sistem anggaran berbasis kinerja secara menyeluruh.

\section{b. Analisis Varians Belanja Langsung Tiap Komponen Belanja}

Penjelasan selisih lebih anggaran baik untuk komponen belanja pegawai, komponen belanja barang dan jasa, maupun komponen belanja modal untuk periode anggaran Pemda X tahun 2011 dan 2012.

\section{Tabel 2. Varians Belanja Langsung Tiap Komponen Belanja}

\begin{tabular}{llccc}
\hline Tahun & Komponen Belanja Langsung & $\begin{array}{c}\text { Anggaran set elah } \\
\text { perubahan }\end{array}$ & Realisasi & \% \\
\hline \multirow{2}{*}{2011} & Belanja Pegawai & $57,594,155,300$ & $49,554,841,751$ & $86 \%$ \\
& Belanja Barang dan Jasa & $320,793,080,452$ & $288,416,500,107$ & $90 \%$ \\
& Belanja Modal & $328,744,168,259$ & $182,537,992,819$ & $56 \%$ \\
\multirow{2}{*}{2012} & Belanja Pegawai & $62,967,956,475$ & $52,044,164,985$ & $83 \%$ \\
& Belanja Barang dan Jasa & $358,025,486,091$ & $298,317,502,723$ & $83 \%$ \\
\hline
\end{tabular}

Sumber: LRA unaudited BPK, Data diolah (2014)

Data tabel tersebut menunjukkan bahwa terjadi selisih lebih anggaran yang sangat signifikan untuk komponen anggaran belanja modal di mana untuk periode anggaran tahun 2011 anggaran hanya terserap 56\% dan untuk tahun 2012 anggaran 
hanya terserap sebesar 75\% (relatif lebih rendah jika dibandingkan dengan dua komponen belanja langsung lainnya).

Salah satu indikasi yang bisa dideteksi dari terjadinya selisih lebih anggaran yang sangat signifikan atas belanja modal adalah adanya sejumlah program kerja yang melibatkan akuisisi aset jangka panjang yang tidak mampu direalisasikan oleh Pemda X di tahun 2011 dan tahun 2012. Kondisi ini harus menjadi perhatian penting karena pada dasarnya komposisi belanja modal suatu pemerintah, khususnya di negara berkembang seperti Indonesia, menduduki peranan yang penting guna memacu pertumbuhan perekonomian. Belanja modal dalam hal ini merupakan injektor utama suatu pemerintahan untuk memicu terjadinya pertumbuhan perekonomian di daerahnya (Oluwatobi dan Ogunrinola, 2011; Nasiru, 2012).

Masih terkait dengan varians belanja langsung untuk tiap komponen belanja, di tahun anggaran 2011, terjadi ketimpangan antara proporsi belanja langsung per komponen belanja yang ada dalam APBD dengan yang ada dalam LRA Pemda X.

Tabel 3. Proporsi Alokasi Belanja Langsung

\begin{tabular}{clrr}
\hline TAHUN & KOMPONEN BELANJA & ANGGARAN & REALISASI \\
\hline \multirow{2}{*}{2011} & BELANJA PEGAWAI & $8 \%$ & $10 \%$ \\
& BELANJA BARANG DAN JASA & $45 \%$ & $55 \%$ \\
& BELANJA MODAL & $46 \%$ & $35 \%$ \\
& TOTAL & $\mathbf{1 0 0 \%}$ & $\mathbf{1 0 0 \%}$ \\
\multirow{2}{*}{2012} & BELANJA PEGAWAI & $7 \%$ & $7 \%$ \\
& BELANJA BARANG DAN JASA & $39 \%$ & $41 \%$ \\
& BELANJA MODAL & $54 \%$ & $52 \%$ \\
\hline & TOTAL & $\mathbf{1 0 0 \%}$ & $\mathbf{1 0 0 \%}$ \\
\hline
\end{tabular}

Sumber: LRA unaudited BPK, Data diolah (2014)

Di tabel tersebut dapat dilihat bahwa anggaran belanja modal menduduki porsi terbesar dari total belanja langsung yang dianggarkan (46\%) jika dibandingkan dengan dua komponen belanja langsung lainnya, yaitu anggaran belanja pegawai (8\%) dan anggaran belanja barang dan jasa (45\%). Namun, hal tersebut berlainan dengan realisasi penggunaan anggaran yang terjadi di tahun 2011 di mana justru proporsi terbesar dari realisasi belanja langsung ada pada komponen belanja barang dan jasa (55\%), sedangkan realisasi belanja pegawai menduduki porsi $10 \%$ dan realisasi belanja modal hanya menduduki porsi $35 \%$ dari total realisasi belanja langsung Pemda $\mathrm{X}$ untuk tahun anggaran 2011.

Satu hal yang perlu diperhatikan selanjutnya dari tabel 3 adalah proporsi alokasi belanja langsung terhadap belanja modal. Berdasarkan pemaparan Bambang Agus Salam, peneliti dari Asian Development Bank (ADB) dalam Majalah Komunitas terbitan Januari 2009, belanja publik (belanja modal) idealnya 70\% sampai $80 \%$ dari APBD. Namun yang terjadi di Pemda X untuk tahun 2011 dan tahun 2012 
adalah tidak demikian, di mana alokasi belanja langsung ke komponen belanja modal masih berada di bawah standar ideal yang disebutkan sebelumnya.

Hal tersebut di atas menjadi suatu masalah yang layak untuk dicermati dan kemudian dicarikan solusi penanganannya dikarenakan pada dasarnya belanja modal menduduki peranan penting bagi pertumbuhan ekonomi dan kemajuan suatu daerah atau negara. Hasil dari penelitian yang dilakukan oleh Nasiru (2012) menyatakan bahwa porsi belanja modal pemerintah memiliki pengaruh dan korelasi yang positif dan signifikan terhadap pertumbuhan ekonomi. Jika dihubungkan dengan konteks Indonesia sebagai salah satu negara berkembang, lebih lanjut Nasiru (2012) memaparkan bahwa penekanan terhadap alokasi belanja modal (capital expenditure) dibandingkan dengan belanja yang sifatnya jangka pendek (current expenditure) harus menjadi agenda utama dari negara-negara berkembang seperti Indonesia karena belanja modal akan berdampak pada perbaikan infrastruktur daerah dan pada kelanjutannya akan memicu pertumbuhan iklim investasi dan aktivitas ekonomi sehingga pada akhirnya akan berdampak positif pada kemajuan negara tersebut.

Pernyataan Nasiru (2012) senada dengan hasil dari penelitian yang dilakukan oleh Cooray (2009) yang menyatakan bahwa optimalisasi alokasi dan penggunaan belanja modal serta peningkatan efektivitas modal publik dapat mengakibatkan pertumbuhan yang lebih baik dengan syarat bahwa optimalisasi alokasi belanja tersebut harus disertai dengan adanya tata pamong yang baik untuk menghindari aktivitas penyalahgunaan dana yang tersedia. Tata pamong yang baik menjadi persyaratan utama dalam hal ini dikarenakan jika pemanfaatan dan eksekusi pelaksanaan belanja modal tidak dijalankan secara benar dan taat azas, maka belanja ini justru akan memicu terjadinya penyalahgunaan uang rakyat dalam bentuk tindakan korupsi oleh pemerintah dan berujung pada inefisiensi pembangunan di suatu negara maupun di suatu daerah (Oluwatobi dan Ogunrinola, 2011).

\section{c. Varians dan Proporsi Belanja Langsung Tiap SKPD}

Informasi menunjukkan bahwa terdapat varians belanja langsung tiap SKPD di Pemda X untuk tahun anggaran 2011 dan 2012.

Tabel 4. Lima Urusan yang Memiliki Tingkat Realisasi Belanja Langsung Terkecil Terhadap Anggarannya di SKPD Pemda X Tahun 2011

\begin{tabular}{llrrr}
\hline \multirow{2}{*}{ NO } & \multicolumn{1}{c}{ URUSAN } & \multicolumn{2}{c}{ TAHUN 2011 } \\
TOTAL
\end{tabular}

El-Muhasaba, Vol. 7, No 1, Januari 2016 
Tabel 5. Lima Urusan yang Memiliki Tingkat Realisasi Belanja Langsung Terkecil Terhadap Anggarannya di SKPD Pemda X Tahun 2012

\begin{tabular}{|c|c|c|c|c|}
\hline \multirow{2}{*}{ NO } & \multirow{2}{*}{ URUSAN } & \multicolumn{3}{|c|}{$\begin{array}{l}\text { TAHUN } 2012 \\
\text { TOTAL }\end{array}$} \\
\hline & & $\begin{array}{l}\text { Anggaran setelah } \\
\text { perubahan }\end{array}$ & Realisasi & $\%$ \\
\hline 1 & $\begin{array}{l}\text { Otonomi Daerah, Pemerintahan Umum, } \\
\text { Administrasi Keuangan, Perangkat Daerah, } \\
\text { Kepegawaian dan Persandian }\end{array}$ & $156,085,531,756$ & $134,449,512,009$ & $86 \%$ \\
\hline 2 & Perhubungan & $17,888,868,769$ & $13,472,913,195$ & $75 \%$ \\
\hline 3 & Sosial & $12,377,874,000$ & $9,088,836,658$ & $73 \%$ \\
\hline 4 & Pendidikan & $195,319,496,120$ & $104,566,097,530$ & $54 \%$ \\
\hline 5 & Kependudukan dan Catatan Sipil & $21,825,385,000$ & $7,307,237,459$ & $33 \%$ \\
\hline
\end{tabular}

Secara keseluruhan dapat dinyatakan terjadi selisih lebih anggaran untuk tiap SKPD baik di tahun 2011 maupun di tahun 2012. Namun yang perlu diperhatikan selanjutnya adalah ketidakmerataan varians yang terjadi (ketimpangan) antara varians pada satu SKPD dengan varians pada SKPD lainnya. Dalam hal ini, pada sebagian SKPD terjadi selisih lebih anggaran yang tidak begitu signifikan, namun di sisi lain terjadi selisih lebih anggaran yang sangat signifikan pada beberapa SKPD. Beberapa SKPD yang terjadi selisih lebih anggaran yang sangat signifikan salah satunya adalah SKPD Dinas Pendidikan di mana untuk tahun anggaran 2011, hanya sebesar 52\% dari total anggaran belanja langsung yang mampu direalisasikan (48\% tidak terserap) dan untuk tahun 2012 hanya sebesar 54\% dari total anggaran belanja langsung yang terserap ( $46 \%$ tidak terserap).

Varians belanja langsung untuk masing-masing SKPD yang dipaparkan pada tabel 4 dan 5 menjadi suatu hal yang perlu untuk dicermati. Hal tersebut dikarenakan ketepatan alokasi belanja langsung pada urusan-urusan yang produktif akan berdampak positif terhadap pertumbuhan dan kemajuan suatu pemerintahan. Hal ini senada dengan apa yang dinyatakan oleh Jin dan Zhang (2011) yang menyatakan bahwa belanja pemerintah daerah yang sifatnya produktif yang sifatnya langsung mengarah pada aktivitas pembangunan ekonomi dan pengembangan ilmu pengetahuan dan teknologi terbukti memiliki dampak yang positif terhadap pertumbuhan ekonomi dan iklim investasi dari daerah yang bersangkutan. Lebih lanjut, Jin dan Zhang (2011) menjelaskan bahwa belanja untuk urusan pendidikan yang dikeluarkan oleh pemerintah daerah, jika tepat penggunaannya, akan bersifat sebagai investasi jangka panjang yang mana dampat positif yang dihasilkan tidak secara instan didapatkan, melainkan akan menghadirkan manfaat yang sifatnya jangka panjang.

Apa yang dikemukakan oleh Jin dan Zhang (2011) juga sejalan dengan hasil penelitian Oluwatobi dan Ogunrinola (2011) serta Nasiru (2012) yang menunjukkan hubungan positif antara belanja pemerintah yang ditujukan untuk upaya pengembangan 
sumber daya manusia terhadap pertumbuhan ekonomi. Adapun contoh dari belanja yang dimaksud adalah belanja yang dialokasikan untuk urusan pendidikan dan belanja untuk urusan kesehatan.

Juga terkait dengan pentingnya alokasi belanja langsung untuk urusan pendidikan, Bose dan Osborn (2007) menegaskan bahwa pemerintah seharusnya menekankan optimalisasi alokasi belanja terhadap urusan-urusan yang berhubungan langsung dengan upaya pengembangan kualitas sumber daya manusia, seperti belanja pendidikan, karena tipe-tipe belanja semacam ini memiliki dampak jangka panjang yang positif terhadap kesejahteraan ekonomi dari daerah yang bersangkutan. Hal tersebut sejalan dengan apa yang dinyatakan oleh Saraswati (2012), yaitu bahwasannya pembangunan suatu daerah ataupun suatu negara erat korelasinya dengan upaya pengembangan pendidikan di daerah/negara tersebut.

Selain penekanan alokasi belanja langsung untuk urusan pendidikan dan kesehatan, alokasi belanja langsung untuk beberapa urusan lain juga diduga memiliki peran penting bagi kemajuan suatu negara atau daerah. Hasil dari penelitian Habib dan Miller (2000) menyatakan bahwa belanja di bidang transportasi dan komunikasi berdampak pada tumbuhnya investasi di negara-negara maju. Sedangkan belanja untuk aktivitas keamanan sosial dan kesejahteraan memicu pertumbuhan investasi di negara-negara berkembang. Di sisi lain, hasil kajian Fan dan Rao (2003) menunjukkan bahwa di Afrika, belanja pemerintah di bidang pertanian dan kesehatan berperan penting dalam memicu pertumbuhan ekonomi. Sementara itu, di Asia, beberapa komponen belanja pemerintah yang terbukti secara empiris mampu memicu terjadinya pertumbuhan ekonomi adalah belanja di bidang pertanian, pendidikan serta di area pertahanan dan keamanan.

\section{PENUTUP}

Berdasarkan pembahasan di atas maka beberapa kesimpulan yang dapat diambil dari analisis belanja langsung Pemda X tahun anggaran 2011-2012 adalah telah terjadi varians belanja dimana jumlah realisasi belanja langsung untuk tahun 2011 dan tahun 2012 lebih kecil dibandingkan dengan jumlah anggarannya. Satu indikasi yang bisa diambil atas terjadinya varians tersebut adalah adanya kelemahan dan kekurangtepatan aktivitas proyeksi anggaran belanja langsung yang dilakukan oleh masing-masing SKPD Pemda X karena perumusan anggaran yang masih belum mendasarkan pada prinsip anggaran berbasis kinerja.

Salah satu varians belanja langsung yang signifikan terjadi pada komponen anggaran belanja modal. Kondisi ini menjadi catatan penting orientasi agenda pembenahan utama bagi Pemda X karena pengeluaran untuk belanja modal akan berdampak pada perbaikan infrastruktur daerah dan pada akhirnya akan berdampak positif pada kemajuan Pemda X. Adapun salah satu SKPD yang mengalami selisih lebih anggaran yang sangat signifikan adalah SKPD Dinas Pendidikan di mana untuk 
tahun anggaran 2011 hanya terserap 52\% dan untuk tahun 2012 hanya terserap sebesar $54 \%$.

Selanjutnya, beberapa implikasi penelitian yang perlu diperhatikan yaitu bahwasannya aparatur Pemerintah Daerah belum memiliki pola pikir dan perilaku yang terintegrasi dan komprehensif untuk menerapkan sistem perencanaan dan penganggaran berbasis kinerja. Selain itu, dari penelitian ini juga dapat dilihat bahwa belum optimalnya penyerapan anggaran belanja langsung dapat mempengaruhi perkembangan pembangunan di Pemerintah daerah. Dari beberapa implikasi tersebut kemudian dapat dijadikan sebagai bahan pertimbangan bagi Pemda $\mathrm{X}$ secara khusus dan negara secara umum untuk menfokuskan pembenahan pada sistem penganggarannya dengan secara komprehensif berkomitmen untuk menerapkan sistem anggaran berbasis kinerja untuk efisiensi dan efektifitas pemanfaatan anggaran daerah.

Adapun beberapa saran yang bisa dijadikan sebagai acuan perbaikan selanjutnya dari analisis belanja langsung Pemda $X$ adalah bahwa seharusnya ada linieritas antara belanja langsung yang dianggarkan dengan belanja langsung yang direalisasikan dengan penggunaan prinsip anggaran berbasis kinerja yang titik tekannya adalah anggaran mengikuti kinerja yang hendak dicapai, bukan sebaliknya. Dengan pola demikian, diharapkan keterserapan belanja, khususnya belanja langsung, akan bisa optimal karena sesuai dengan program kerja yang akan dieksekusi dan kinerja yang dicita-citakan. Selanjutnya, Pemda X hendaknya meningkatkan alokasi belanja langsung pada belanja modal serta mengoptimalkan keterserapan atas anggarannya. Hal demikian dikarenakan belanja modal menduduki peranan penting bagi pertumbuhan ekonomi dan kemajuan suatu daerah atau negara. Selain itu, Pemda $\mathrm{X}$ juga hendaknya memperhatikan ketepatan alokasi anggaran belanja langsung untuk urusan-urusan yang dinilai produktif, yaitu urusan yang berorientasi pada pembangunan kapasitas sumber daya manusia contohnya urusan pendidikan, kesehatan, dan ketenagakerjaan.

\section{DAFTAR PUSTAKA}

Andriani, Wiwik. Ermataty Hatta. 2012. Analisis Penerapan Anggaran Berbasis Kinerja Pada Pemerintah Pusat (Studi pada Politeknik Negeri Padang). Jurnal Akuntansi \& Manajemen, Vol 7 No.2 Desember, hal 24-35

Anthony RN.1985. Games Government Accountants Play. Harvard Business Review. Ball, S.J. 2004. Case Study. Dalam Kuper, A., and Kuper, J. (editor). The Social Science Encyclopedia, Third Edition (p. 92). Routledge. London.

Bastian, I. 2006. Akuntansi Sektor Publik: Suatu Pengantar. Jakarta:Penerbit Erlangga.

Bose, Niloy. Denise R. Osborn. 2007. Public Expenditure And Economic Growth: A Disaggregated Analysis For Developing Countries. The Manchester School Vol 75 No. 5 September. 
Carruthers, B.G. 1995. Accounting, Ambiguity, and The New Institutionalism, Accounting, Organizational and Society 20 (4): 313-328.

Carter, William K, Milton F. Usry, 2004, Cost Accounting $14^{\text {th }} E d$, Thomson Learning (CAR). Collins, R. 1979. The Credential Society. Academic Press. New York.

Cooray, Arusha V. 2009. Government Expenditure, Governance and Economic Growth. University of Wollongong Research Online Faculty of Commerce - Papers (Archive).

DiMaggio, P. J., and Powell, W. W. 1983. The Iron Cage Revisited: Institutional Isomorphism and Collective Rationality in Organizational Fields. Dalam W. W. Powell \& P. J. DiMaggio (editor). The New Institutionalism in Organizational Analysis (p. 6382). Chicago:The University of Chicago Press.

Direktorat Jenderal Perimbangan Keuangan (DJPK) Kementerian Keuangan Republik Indonesia. 2013. Laporan Evaluasi Belanja Modal Daerah.

Fan, Shenggen. Neetha Rao. 2003. Public Spending In Developing Countries: Trends, Determination, And Impact. Environment and Production Technology Division Discussion Paper no. 99.

Gilmour, John B. David E. Lewis. 2005. Assessing Performance Budgeting at OMB: The Influence of Politics, Performance, and Program Size. Journal of Public Administration Research and Theory, 16: 169-186.

Glaser, Mark A. 2007. Networks and Collaborative Solutions to Performance Measurement and Improvement in Sub-Saharan Africa. Dalam A. Shah (Ed.), Performance accountability and combating corruption (pp. 233-254). Washington DC: The World Bank.

Habib, Ahmed. Stephen M. Miller. 2000. Crowding-Out And Crowding-In Effects Of The Components Of Government Expenditure. Contemporary Economic Policy; Jan 2000; 18, 1; pg. 124.

Halim, Abdul. 2007. Akuntansi Sektor Publik: Akuntansi Keuangan Daerah. Edisi 3. Jakarta: Salemba 4.

Hou, Yilin. Robin S. Lunsford. Katy C. Sides. Kelsey A. Jones. 2011. State PerformanceBased Budgeting in Boom and Bust Years: An Analytical Framework and Survey of the States. Public Administration Review, May-June.

Jin, Tao. Jianhui Zhang. 2011. Effect of Local Government Expenditure on the Ratio of Output to Capital: Evidence from Panel Data at China's Provincial Level. Front. Econ. China 2011, 6(2): 249-270.

Kainde, Christian. 2013. Analisis Varians dan Pertumbuhan Belanja Daerah Pada Pemerintah Kota Bitung. Jurnal EMBA Vol.1 No.3 Juni 2013, Hal. 393-400.

Kuncoro, Haryo. 2008. Variansi Anggaran Dan Realisasi Anggaran Belanja Studi Kasus Pemerintah Daerah Provinsi DKI Jakarta. Jurnal Manajemen Teori dan Terapan, Tahun 1, No. 2, Agustus.

Larson, M.S. 1977. The Rise of Prefessionalism: A Sociological Analysis. University of California Press. Berkeley.

Lippi, A. 2000. One theory, many practices. Institutional allomorphism in the managerialist reorganization of Italian local governments, Scandinavian Journal Management 16(2000): 455-477.

Mardiasmo. 2009. Akuntansi Sektor Publik. Yogyakarta: Penerbit Andi.

El-Muhasaba, Vol. 7, No 1, Januari 2016 
Meyer, J.W., and Rowan, B. 1977. Institutionalized Organizations: Formal Structure as Myth and Ceremony. Dalam W. W. Powell \& P. J. DiMaggio (editor). The New Institutionalism in Organizational Analysis (p. 41-62). Chicago: The University of Chicago Press.

Meyer, J.W. 1996. Otherhood: the Promulgation and Transmission of Ideas in the Modern Organizational Environment. Dalam B. Czarniawska, \& G. Sevon (editor). Berlin Translating Organizational Change (p. 241-252). de Gruyter.

Miles, M. B., and Huberman, A. M. 1992. Analisis data Kualitatif. Jakarta: Universitas Indonesia Press.

Nasiru, Inuwa. 2012. Government Expenditure and Economic Growth in Nigeria: Cointegration Analysis and Causality Testing. Academic Research International, Vol. 2, No. 3, May.

Oluwatobi, Stephen O., Oluranti Ogunrinola I. 2011. Government Expenditure on Human Capital Development: Implications for Economic Growth in Nigeria. Journal of Sustainable Development Vol. 4, No. 3; June.

Rahayu, Sri. Unti Ludigdo. Didied Affandy. 2007. Studi Fenomenologis Terhadap Proses Penyusunan Anggaran Daerah Bukti Empiris Dari Satu Satuan Kerja Perangkat Daerah Di Provinsi Jambi. Simposium Nasional Akuntansi X Makasar, 26-28 Juli.

Raghunandan, Moolchand. Narendra Ramgulam. Koshina Raghunandan-Mohammed. 2012. Examining the Behavioural Aspects of Budgeting with particular emphasis on Public Sector/Service Budgets. International Journal of Business and Social Science, Vol. 3 No. 14, Special Issue - July.

Sancoko, B., Djang, T.A.S., Noor, C.M., Sumini, dan Hery, T. 2008. Kajian Terhadap Penerapan Penganggaran Berbasis Kinerja di Indonesia. Jakarta: Departemen Keuangan Republik Indonesia.

Saraswati, Erwin. 2012. Public Spending Education and Inequality: A Case Study in Indonesia. International Journal of Social Science and Humanity, Vol. 2, No. 5, September.

Schick, A. 1996. The Spirit Of Reform: Managing the New Zealand State Sector in a Time of Change. A Report Prepared for the State Services Commission and The Treasury. New Zealand.

Scott, W. Richard. 2004. Institutional Theory: Contributing to a Theoretical Research Program. Dalam Great Minds in Management: The Process of Theory Development, Ken G. Smith and Michael A. Hitt, eds. Oxford UK: Oxford University Press.

Sewing, J.H. 2010. Corporate Divestiture Management: Organizational Techniques for Proactive Divestiture Decision-Making. Gabler Verlag. Germany. http://books. google. co.id/. 4 Februari 2011.

Sugiyono. 2008. Memahami Penelitian Kualitatif. Bandung: Alfabeta.

Vinnari, Eija, M., Salme N'asi. 2008. Creative Accrual Accounting In The Public Sector: 'Milking' Water Utilities To Balance Municipal Budgets And Accounts. Financial Accountability \& Management, 24(2), May, 0267-4424.

Wahyuni, T. 2007. Penganggaran Berbasis Kinerja Pada Kementerian/Lembaga : Masih Harus Banyak Berbenah. http://www.anggaran.depkeu.go.id/web-content-list. asp? ContentId=97. (Diakses tanggal 13 Juni 2014). 
Yin, R.K. 1982. Case Study Research. Beverly Hills. Sage Publication. M. Djauzi Mudzakir (Penterjemah). 2004. Studi Kasus. Edisi kelima. Jakarta: PT Raja Grafindo Persada. 